\title{
UNRULY PUPPETS: PRODUCING THE URBAN POOR IN A BANGLADESHI TELEVISION IDOL COMPETITION
}

\author{
Din M. Sumon Rahman* \\ University of Liberal Arts Bangladesh, House 56, Road 4/A, Dhanmondi, \\ Dhaka, Bangladesh \\ E-mail: sumon.rahman@ulab.edu.bd
}

Published online: 30 July 2021

To cite this article: Rahman, D. M. S. 2021. Unruly puppets: Producing the urban poor in a Bangladeshi television idol competition. International Journal of Asia Pacific Studies 17 (2): 193-216. https://doi.org/10.21315/ijaps2021.17.2.8

To link to this article: https://doi.org/10.21315/ijaps2021.17.2.8

\begin{abstract}
Magic Tin Chakar Taroka (Magic Three-Wheeler Star) or Tin Chaka (ThreeWheeler) is a reality competition to find music talent exclusively from the urban poor of Dhaka city. This programme was shown on Bangladeshi satellite television in 2008. The present article is an ethnographic exploration of the Tin Chaka event which demonstrates how the cultural identity of the urban poor in Dhaka has been performed by the production of ordinary celebrities in the visual media. In doing so, a combination of on-screen and off-screen observations were undertaken for a period of six months which was complemented by semiological interpretation of adverts, jingles and other visual materials. In this article, I argue that, despite its admirable inclusivity and thereby remarkably instant acceptance by the audience, the reason behind the discontinuation of Tin Chaka in following years lies in the inscriptions of the show as a charitable undertaking, an act which has often been performed in the reality television programmes in the name of "democratisation".
\end{abstract}

Keywords: urban poor, cultural identity, reality television, democratisation, Dhaka

\section{INTRODUCTION}

On 25 October 2008, a rickshaw-puller named Omar Ali was awarded as the first Tin Chakar Taroka (the idol of the Tin Chaka show) of Bangladesh in the final event of the music reality show named Tin Chaka (Three-Wheeler). 
The final event was held in one of the most prestigious auditoriums of Dhaka and attended by the leading politicians, bureaucratic personnel and cultural elite of the city. In a follow-up interview with a newspaper, Omar Ali firmly announced his decision of giving up rickshaws and taking up music as his career for the rest of his life (Prothom Alo 2008a). That announcement was given at a time when Omar was receiving an impressive number of performance invitations from all over the country. He also had trouble finding a schedule for the warm reception which was to be held in his native village to celebrate his recently acquired stardom. It was just after the next month when Mamtaz, one of the leading musicians of the country and a judge of Tin Chaka, remarked in a newspaper interview that "the poor people also dream of being musicians" (Prothom Alo 2008b). It was also just two months before when Omar, in a follow-up interview with me, was describing his situation as someone being hanged up in the middle of nowhere (personal communication, 27 December 2008).

Omar Ali, a bearded rickshaw-puller in his mid 50s, was provided with a short-lived stardom by dint of a television idol competition named Tin Chaka (literally "three wheelers", i.e., rickshaws) organised in 2008 by ATN Bangla, a private television channel intending to find music talent from a particular section of the urban poor of Dhaka, e.g., from people working with three-wheelers. Based on an ethnographic exploration of this one-season reality programme, the present article shows how the cultural identity of the urban poor has been produced and performed in the scope of a television reality show and how the hybrid nature of this subcultural identity has been appropriated by visual media.

Dhaka is among the most crowded cities on Earth; nearly half of its population lives in slums, squatter settlements and on the urban fringes. Those informal city-dwellers, by the sheer volume of their consumption and with the advent of cheap music-listening technologies, have radically re-shaped the structure of the music industry. Since the 1980s, an emerging trend of popular music, sometimes called "urban folk", has been dominating the audio media and a new generation of artists and musicians has come into the scene by dint of, among other factors, the decentralisation of the music industry itself. In its lyrics, this new hybrid often deals with issues to do with the urban poor and in its melodies appropriate traditional folk tunes. Given that it is a kind of music that is primarily aimed at the poor people of the city, its success in terms of a growing share of the audio industry apparently indicates that the audio cassette culture of Dhaka city has been largely restructured to accommodate the taste of its poor consumers (Mohammad 2014). 
The rise of the urban poor as popular music consumers and the prevalence of urban folk music in the audio industry of Dhaka in the last two decades was reason enough for the visual media to try and grab a share of that pie. Mamtaz, the most prominent Bangladesh urban folk music icon, has been a regular performer on Bangladeshi televisions since the 1990s even though her music was not received enthusiastically by the educated upper classes, mainly because of the apparent lack of sophistication that the elite used to find in the lyrics of music they consumed. In 2003, one popular television magazine show Ittādi discovered a "gifted" music talent in Akbar, a rickshaw-puller. His performance in the context of his class background was highly appreciated by the audience. Eventually Akbar left rickshaws behind and moved to Dhaka to begin his career as a pop musician. In 2005, the first Bangladesh idol (locally known as Close Up One) was won by a young man, Nolok, who used to sing on trains and buses to raise money for his mother's medical treatment. This story was only revealed in the programme when Nolok was in the top 10, and the subsequent deluge of support was a deciding factor in his win. SMS votes for Nolok found unprecedented support for him throughout the country. Even beggars formed syndicates to collectively vote for Nolok from mobile phone shops. ${ }^{2}$ Briefly, these are the major events through which the era of the ordinary celebrity found its way into the Bangladeshi visual media.

This study examines how the consumers of urban folk music in the context of Bangladeshi visual media contributes to the understanding of local cultural politics. There are certain kinds of optimism and pessimism dominating the analysis of the media, as Baudrillard and Maclean (1985) observe. Marshall McLuhan, among others, is technologically optimistic about media's capacity to produce a transparency of information and communication through a generalised planetary communication. Besides, there are ideological optimisms too, which lead the scholars to think that the media ensures mass participation in the productive process that empowers the masses. The pessimistic view generally considers the media as intransitive, opposed to mediation and "speech without response" (Baudrillard and Maclean 1985: 577). In this view, the mass media, the television for instance, has been seen as an ideological device that circulates among the audience the view of the ruling class. It is considered as a kind of capitalist economy in the way that it, both materially and symbolically, reproduces the capitalist relations that have prevailed in society (Rajagopal 2001: 4). Baudrillard, as one of the pessimists about the social role of the media, considers the mass media, including television, as neither beneficial 
for the masses, nor manipulative, because there is no relationship between a system of meaning and a system of "simulation" in the media (Baudrillard and Maclean 1985: 579). For Baudrillard, "simulation" is the imitation of a real-world process which is different from "simulacra" where the latter are copies for things which have no original (Baudrillard 2001). However, with the prevalence of reality television, the relationship between the media and democracy has been reinvestigated. Hartley (1999) argues that television, as a "transmodern" teacher, has witnessed the democratisation of the media by producing, for instance, cultural citizenship in several popular and widely participatory programmes (Hartley 1999: 161-63). Turner (2010) questions the idea of democratisation of the media and argues that the media access to the "ordinary people" is an occasional and accidental consequence of the "entertainment" since the category of "celebrity" never ceases to be exclusive or hierarchical (Turner 2010: 16). Both Hartley (1999) and Turner (2010) are agreed on the point that media opens up and provides access to the "ordinary people". In the scope of the present article, an interesting dimension arises regarding the use of the term "ordinary people". In Bangladesh, the "ordinary people" can be divided into two groups: television viewers and non-viewers. The non-viewership can be caused either by the lack of access or the lack of interest in the culture of the urban middle class that television usually focuses on, or by both. This article focuses on how the urban poor, being perceived mostly as nonviewers of pay TV programmes in Bangladesh and therefore a potential consumer group to address, has been represented as an entertainment subject through the television production of a music idol competition, and how the prevailing social relations in the city have been morally inscribed and culturally negotiated in this process.

In 2001, the reality television competition UK Pop Idol began in the United Kingdom with the mission of finding solo musical talent across the country, tested the basis of public opinion, and soon it became a global phenomenon. ${ }^{1}$ There has since been a significant growth of scholarly attention on the reality television phenomenon and their franchises in the non-western societies (Lockard 1998; Jacobs 2007; Moran 2009; Tay 2011). Even though the same format has been followed, the same reality show creates different momentum for different countries and regions and contributes to the original form as well. For example, Jacobs (2007) shows how the franchise of the reality show Big Brother in Africa has ignited many debates on globalisation, democracy, class power, race and gender, South African "neo-colonialism" and so on. The franchise of Big Brother 
in the Balkan region, as Volcic and Andrejevic (2009) explain, was a project intended to draw on the political and cultural reconciliation in wartorn Balkan region as a form of a "commercial nationalism" by selling "Yugo-nostalgia" or belongingness for the former Yugoslavia. Similarly, Tay (2011) examines how an idol franchise created a greater regional identity through the performance of the Asian Idol competition. These are a few examples of adaptation where reality televisions intend to create greater regional identities in Africa, Asia and the post-war Balkans with clear political connotations. In the present case, the pop idol format has been used in a smaller context, neither to ignite any nationalistic sentiment nor to create any greater-regional identity, but to commercially appropriate the cultural identity of the most marginalised community of a Third World city that constitutes half of its population.

\section{METHODOLOGY}

As mentioned, participant observation was the key instrument for data collection. Based on the different ethnographic positions identified by Burgess (1990), I chose the "participant-as-observer" position in order to engage more as a participant than as an observer. I became aware of the Tin Chaka programme through some Bengali web-blogs at its initial stage, even before it became popular on television. Later, I met online activists who had undertaken a mission to support the "original" creators of Tin Chaka and protect the intellectual property rights of the disadvantaged population or individuals. However, as a researcher, I could neither join them as an activist, nor could I act as as a journalist; rather I stayed somewhere in-between to see the programme's prospect more clearly. Perhaps this strategy made my inclusion in this programme more sustainable, whereas my activist friends lost their interest and access as soon as the creators of Tin Chaka were removed from the programme. I was able to maintain a working relationship with the producer, the production team and the contestants of Tin Chaka and thereby was able to access all the audition rounds, the live recording sessions, press conferences, even some of the pre- and post-production meetings. At the same time, I was able to meet the contestants at their residences, workplaces and in the green rooms of the competition as well. However, the curiosity about my identity was never resolved and eventually the contestants began to consider me as the only "unpublished journalist" around them. This is because I 
was the only "journalist" who conducted interviews, took photographs, talked and met with them on many occasions, but none of it was published anywhere. However, the contestants' perception of my regretful "inability" to publish or my "powerlessness" also helped me to easily get along with them as it opened more informal spaces both with the producer (since I do not publish, I am "safe") and the contestants (because I am as powerless as they are). This performative identity of myself as the researcher was shaped sometimes quite independently of my intentions, during my fieldwork from June 2008 to January 2009 in Dhaka. I also paid regular visits to an urban slum, Korail, to measure the impact of this programme on its audience who lived there. I also observed the way the programme has been exposed to different news media and community blogs. I had several occasional informal chats with the contestants, producers and other stakeholders on many occasions which were noted in my field diary. The accidental and imposed identity of a journalist helped me access my stakeholders at all possible levels.

\section{THE TIN CHAKA STORY}

This story began with an initiative taken by two young men - Shishir, a media broker, and Tushar, an entrepreneur who ran a music recording business. The idea of the Tin Chaka music competition had originally been conceived by Shishir but soon he became dependent on Tushar to accomplish the event. Shishir observed closely the musical talent among the rickshaw pullers as his elder brother was a rickshaw puller who had died a few years earlier. Therefore, for him, Tin Chaka, in addition to its business potential, was also a kind of a tribute for his brother with whom he had visited rickshaw garages in his boyhood, and where he also gained a sense of the music talent among the urban poor (personal communication, 10 October 2008). However, Tin Chaka was not a very ambitious project for Shishir. It was conceived as a competition to identify a handful of good music performers among the urban poor with whom he could release an audio $\mathrm{CD}$ in the upcoming Eid festival. In order to run the event, he fixed an entry fee (Taka 35, equivalent to USD0.50) for each competitor as the source of his revenue. He printed posters advertising the competition, along with his contact number, and had them pasted on rickshaws. Table 1 shows the programme structure of Tin Chaka and Figure 1 shows the Tin Chaka poster on the rickshaw. 
The response to Tin Chaka was very promising. It came not only from rickshaw pullers, but also from auto rickshaw drivers, other professionals of Dhaka city, and from people residing outside the city. That led Shishir to think of the competition on a slightly broader scale and he involved Tushar in the team. Initially the contract between them was that Tushar would act as an honorary judge in the competition. Being better connected to the media, Tushar was more able to mastermind this new television concept. He invited his journalist friends to cover this event before the first audition round, meanwhile Shishir also grew ambitious and sought sponsorship opportunities. With the benevolent help of others, he applied for sponsorship from some corporate houses but ultimately was not successful in his bids.

Table 1: The programme structure of Tin Chaka

\begin{tabular}{|c|c|c|}
\hline Event & Status & Time range \\
\hline $\begin{array}{l}\text { 1. Audition rounds } \\
\text { (four auditions in four } \\
\text { different parts of the city) }\end{array}$ & $\begin{array}{l}\text { Never televised as an event, clip shown } \\
\text { in different episodes }\end{array}$ & $\begin{array}{c}\text { May } 2008- \\
\text { July } 2008\end{array}$ \\
\hline 2. Top 20 selection & Performed on stage and then televised & August 2008 \\
\hline 3. Top 10 selection & Performed on stage and then televised & September 2008 \\
\hline 4. Top 3 selection & Performed on stage and then televised & September 2008 \\
\hline 5. Final & Performed on stage and then televised & October 2008 \\
\hline
\end{tabular}

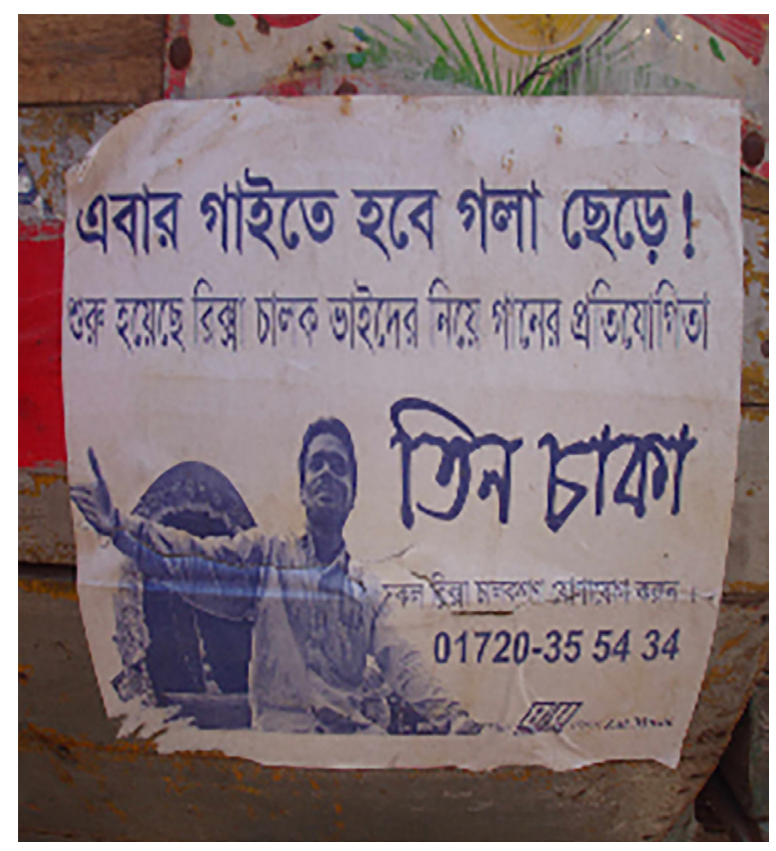

Figure 1: Tin Chaka poster on a rickshaw. 
The first audition round of Tin Chaka took place on 9th May 2008 on the grounds of a primary school in Mirpur, Dhaka. The queue of the prospective participants was so long that the selection process lasted from early in the morning to late in the afternoon. In the afternoon, Munni Saha, a veteran television journalist and producer who works for ATN Bangla, covered this event. The report was broadcasted on ATN Bangla television the same day, giving special attention to this competition. The nature of those who participated in this competition appealed greatly to Munni Saha, who kept an eye on it. She even cooperated with and advised the organisers of the event. Through her mediation, ATN Bangla television entered the scene as a "media partner" of the event. Gaining a new identity, Tin Chaka was again pitched to corporate houses for sponsorship and this time, with the help of ATN Bangla, Shishir and Tushar managed to get several interested parties. Of these, Square Group, one of the leading corporate houses in the country, offered them the most generous deal and became the programme's major sponsor. The same agency had earlier refused the proposal brought to it by Shishir, but now with ATN Bangla behind the programme, the same house agreed to a deal worth 20 times the value of the original bid. ShishirBindu, the company established by Shishir, became the organiser of Tin Chaka. Three successive audition rounds of Tin Chaka were accomplished between May and July 2008.

From the second audition round, Tin Chaka became Magic Tin Chakar Taroka (Magic Three-Wheeler's Star). Here Magic refers to the name of a tooth powder produced by Square Group and later adopted in the title of programme as an explicit mark of their corporate sponsorship. Since the third audition round, the name of Shishir-Bindu ${ }^{3}$ was eliminated from the show and it became very much of an ATN Bangla television event. However, according to the reporter Munni Saha who was gaining a new identity as a television producer by dint of this programme, the absence of Shishir-Bindu's name and logo from the backdrop and posters was an "accident" (personal communication, 29 January 2009).

What was an "accident" earlier became a regular and justifiable incident in the successive sessions. Since then, the most noted media personalities in the country joined this programme as it steadily gained nationwide attention. Asaduzzaman Noor, one of the most celebrated drama icons in the country who was also a member of the parliament in Bangladesh, appeared on stage as the programme's anchor. Mamtaz, one of the country's biggest music icons was appointed as the final judge of the competition, along with the owner of ATN Bangla television, who 
proclaimed himself the "guardian" of those "poverty-stricken musical geniuses" from the top 10 selection round.

The question of the programme's ownership became clear during this period. Shishir and Tushar received a cheque to the value of Taka 2.5 Lacs (USD3,500) from a corporate house for their efforts with, and investments in, Tin Chaka. They were also told that from then on Square Group would handle the programme in the successive years and that they would only be "employed" if it was required. This led Shishir and Tushar to contest the Square Group. The sponsorship contract with Square Group was for one year. Tushar sought legal measures to establish his right over this programme. He maintained close relations with the top 10 contestants to retain his control over the programme. He took a bond from these contestants, using stamps which would bind them to work only with Tushar's recording company for at least one year after the event concluded.

Such a move on Tushar's behalf led ATN Bangla television and the corporate house to a more carefully designed game. They managed to break Shishir and Tushar's partnership by offering Shishir further career opportunities, as he was dependent on the visual media for his livelihood. They also mobilised the contestants against Tushar by disclosing to them the insulting and inhumane bond Tushar took from the artists. As a result, Shishir broke from Tushar and the contestants began to call Tushar a cheat. Later, Omar Ali, the winner of this competition, told me that Tushar was a "criminal" who "hijacked" this programme from an "innocent" Shishir (personal communication, 27 December 2008).

The grand finale of Tin Chaka was astonishingly colourful. It took place in the Bangladesh-China Friendship Convention Centre, one of the best auditoriums in the city. Many of the noted media and political personalities witnessed the final round. As I mentioned in the beginning, Omar Ali, a rickshaw-puller of 55 years, won the competition while two other auto-rickshaw drivers became the runners-up. The performance and life story of Omar Ali and other contestants (shown in pre-recorded video clips) touched the hearts of the audience, as many were seen wiping their eyes during the programme. All invited guests thanked the programme producer for making such a "noble" programme which revealed the talent among the city's poorest people. They also thanked the owner of the television channel for his continual support to such "philanthropic" ventures. Shishir-Bindu was not mentioned throughout the grand finale even once. Though Tushar was present there as a judge, Shishir was not even invited to the event. 


\section{PRODUCING THE URBAN POOR}

With the intervention of the television channel and corporate sponsor, a radical change happened in the production process of Tin Chaka. Previously perceived as a programme made by and for the urban poor, the television version aspired to reach a larger audience. It was produced as an entertainment cum education package for the urban elite, and as an opportunity to encounter the "other half" of the city. When Tushar composed the title song for Tin Chaka, it was rejected both by the channel and the sponsor because, according to them, that title song was "too sophisticated" to represent the urban poor. This implies that the cultural identity of the urban poor has to be produced in a way that reflects what has already been imprinted on the minds of the urban elite, thereby reinforcing their intellectual and moral leadership in the society.

The politics of identity often takes symbolic forms. For instance, a corporate reading of the urban poor is symbolised in this context by the word "magic", the name of a tooth powder being manufactured for the poor. Television promotion of this product often projects an informal economic context in which the use of this tooth powder would enable the urban poor to raise their voices. Jorse bolo! (Speak up loudly!) is the brand slogan for this product. ${ }^{4}$ The same branding happened in Tin Chaka when Square Group appeared as the corporate sponsor of this programme. In the beginning, the brand slogan of this event was Gaite hobe gola chere (Sing with a free voice) but the corporate agency changed it to Jorse gao (Sing loudly) in order to synchronise it with their brand slogan for "Magic tooth powder". Thus, the identity-package of Tin Chaka is revealed: the music talent of the urban poor cannot grow unless it is encouraged by the corporation. The word "magic" also signifies the desire to escape the miseries that have been systematically embedded in the everyday lives of the urban poor. Another instance could be drawn from the removal of Shishir-Bindu's name and logo from the banners and backdrops of Tin Chaka as soon as it became a television event. For Shishir, this removal was symbolic, akin to losing his own identity as an initiator of a programme because of the marriage of convenience between the media and corporate players (personal communication, 10 October 2008). Therefore, Shishir's agenda to re-establish Shishir-Bindu's name and logo in the banners and backdrops of Tin Chaka can be seen as a form of resistance; though futile, this resistance was also symbolic to the question of his own identity. 
After removing Shishir-Bindu from the programme, Tin Chaka began to undergo certain changes. In the audition round, the contestants naturally performed songs of their own choice and in most cases of Tin Chaka, they were mostly the urban folk songs. When the contestant was selected from the audition, the judges and music educators would ask for a list of his favourite songs and which he would like to perform in the next round. As soon as the list was provided, all the urban folk songs were removed and new suggestions were made for that contestant. Even though Mamtaz, the urban folk queen, was a vital part of this competition as a stage judge, some of her songs were also eliminated by the music educators from the contestant's list of choice. The contestants were repetitively told that those "vulgar" songs would not lead them to the top and therefore were harmful to their career. Alternative suggestions were initially made from the stock of pop or movie songs, and then from the folk music tradition if the popular music did not suit the performer. This was how most of the judges had undertaken the "benevolent" mission to "educate" these natural talents, using "proper" knowledge on music and society. Accordingly, they arranged extra grooming sessions where the contestants were taught several aspects of life and society.

The objective of such education is quite clear: to present the urban poor in such a manner that they could no longer be identified as exotic, but rather as people familiar to the urban educated class. Therefore, it seems that from the judges' point of view, Tin Chaka was meant for the consumption of the urban educated class who were, and still are, the regular viewers of television. For its corporate sponsor, Tin Chaka was a promising way to reach the non-viewers of television, a population that forms the potential consumer base for their products. As a matter of fact, Tin Chaka did not act well as the mediator of two different missions with conflicting interests, and could not find a way to unify them in the programme structure; instead, the show swung between these two interests like a pendulum throughout the programme. For example, after the top 20 rounds when the popularity of Tin Chaka was on the decline, the owner of the ATN Bangla asked to make the programme "more entertaining" so that their existing viewers would find it worthwhile watching. As this prescription was followed, Tin Chaka was reported to have lost its appeal in the slums. Under pressure from its corporate sponsor, Tin Chaka then allowed a few Baul songs (the original ones, not the urban folk hybrids) in the competition and the television authority installed a few big screens in the slums to broadcast Tin Chaka after the top 10 rounds ended. This situation is similar to where 
Turner (2010) agrees with Abu-Lughod's (2005) observation in Egypt that television today does not have a "masterplan of purpose" and acts "like an ideological system without an ideological project", the result of which identities are produced in a contingent manner, or on ad-hoc basis, solely for entertainment purposes. By doing so, the media has basically undermined their historically central role in the operation of the public sphere (Turner 2010: 166-167; Abu-Lughod 2005: 193).

\section{PERFORMING THE IDOL}

How does the self-assertion of one's identity take place? In other words, how performative is an autobiography, hence the formation of an identity? The Tin Chaka performers, who seemed to have been in the most glorious stages of their lives, present an opportunity to explore these important questions. During a few one-on-one interviews with some of them, I gained information about their life histories without asking any questions. In this manner, I could see how they reconstructed and performed their biographies in a specific context.

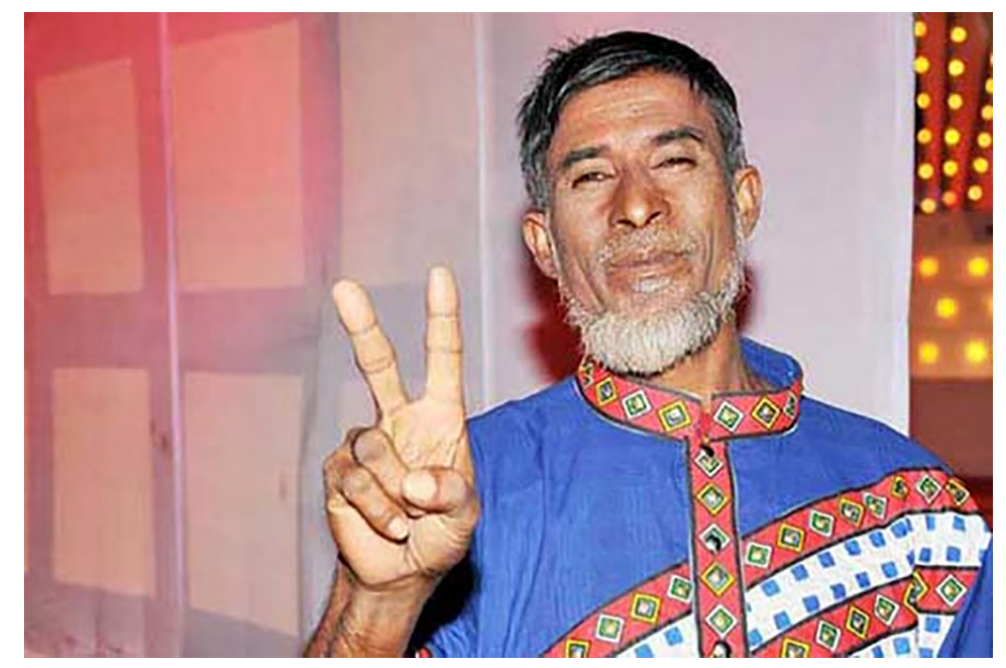

Figure 2: Omar Ali, the Tin Chaka idol.

Omar Ali (55 years old) was a rickshaw puller who lived in a hut near a rickshaw garage in an urban fringe of Dhaka (as shown in Figure 2). The hut was allotted to him by the owner of the garage. He had been known as a singer among his colleagues and in his neighbourhoods since his younger days. Omar Ali migrated to Dhaka city and became a rickshaw puller in the 1970s. It was 20 years ago when Omar Ali saw the billboard for the 
Abbas Uddin Music Academy while he was pulling a rickshaw in Dhaka. He entered the academy and found Mr. Mustafa Zaman Abbasi, a renowned musician and son of the late Abbas Uddin, the legendary folk music performer. Mr. Abbasi was sympathetic towards the rickshaw puller and requested the academy to take in the enthusiastic Omar Ali as a student. It was difficult for Omar Ali to find time for learning music. Moreover, this pursuit was not appreciated by his poverty-stricken family. Nonetheless, he continued this training secretly from time to time, escaping from his job for a few hours when he could. In April 2008, Omar Ali saw a poster for Tin Chaka on the back of a rickshaw and followed it until he memorised the organiser's contact number. He registered for the competition and eventually appeared as one of the most senior competitors. He kept his participation secret until he was selected in the top 20. In the top 10 selection round, after pulling a rickshaw for half a day, Omar Ali arrived very late and was almost announced as an absentee. He had no choice but to work that day so that he could buy food for his family. This story, when told by Omar Ali at the show touched the audience and television viewers very much, and Omar Ali came to prominence for the first time. His commitments, both to his family and to music, were highly appreciated by the presenters and judges of the programme.

Mukhles (45 years old) was not a three-wheeler driver as such. $\mathrm{He}$ was basically a petty shop owner and an occasional folk musician. Attracted by the announcement of Tin Chaka, Mukhles registered for this event while falsely claiming to be an auto-rickshaw driver and impressed the audience with the sweetness of his voice. He also appeared as one of the strongest candidates and surmounted hurdles, one after another, quite easily. It was revealed only at the very late stage of the competition that Mukhles was not a three-wheeler driver. At the time, he was among the top three contestants and video footage of the everyday lives of the three contestants was being collected. His occupational status was concealed by the programme organisers and Mukhles was given quick training in auto-rickshaw driving so that he could at least drive for the purpose of recording the video. He finally managed to finish this competition as one of the runners-up.

Firoz (30 years old) was another impressive singer but was "expelled" from the competition during the top 10 stage. He seemed to be the smartest performer among the 10 short-listed contestants. He had a versatile voice adaptable to many music styles. Apparently, Firoz fulfilled many of the needs of the showbiz media and seemed to have a bright future. But he had a human weakness, a "limitation" which halted his growth quite decisively. 
Firoz displayed tendencies of promiscuity. At every round since the audition, Firoz appeared with a new girl. During the top 10 round, Firoz came with a girl whom he had just married shortly before. While the show was running, the girl's guardians also arrived and discovered that the marriage had taken place, resulting in an embarrassing experience for the organisers. The judges took a serious view of this case and instantly dropped Firoz from the programme.

Abdur Rahman Khokon (45 years old) was another performer who had reached the top three stage in the competition. A resident of the Korail slum in Dhaka, Abdur Rahman was a team member of the Thursday Nights weekly musical performance. ${ }^{5}$ Although a signboard artist by profession, he decided to participate in this competition by highlighting his earlier profession as a rickshaw puller. He soon became a familiar name in Korail after his success in the top 20. Even the ward commissioner of Korail and other influential leaders of this slum started to greet him as a man with promise.

Even though all of the contestants described above confessed in the beginning that the good fortune they had been enjoying was quite unprecedented for them, the way they structured their biographies to justify their present status was quite teleological in nature. For instance, the way Omar Ali presented his biographical package by prioritising some minor incidents over several major life events was basically the reinvention of his identity so as to support his present status as a music artist. This happens at the individual level when a person, in order to rediscover his cultural self, constantly negotiates with his own past until it provides him with a coherent logic. Hence the stories of spending a few days in a music school 20 years back or finding the poster of Tin Chaka also constitute crucial aspects of Omar's biography which, one may guess, would never be repeated if the narration was given in another context. Similarly, the occasional or even rare event of Mukhles being a folk singer, or Abdur Rahman's weekly participation in the Thursday Nights performance at Korail slum, has become significant in the production of meanings about their own lives. These narratives are basically "preferred moments" of their lives with which they get closer to their perceptions of selfhood. And the power of the teleological structure is so provocative that it creates its own chronology of "preferred moments" irrespective of their truth value. Tin Chaka provided these people with two keywords: music and three-wheelers, to make a performative biography for each of them. Operating ideas in such a situation would thus require the re-definition of some crucial issues. 
This was why Abdur Rahman Khokon, who used his former professional identity as a rickshaw puller to gain entry to the programme, justified his act by saying that every single person living in a slum was a rickshaw puller because this was the only "crisis-profession" for the poor in the city (personal communication, 27 December 2008). Thus, Abdur Rahman's negotiation of identity echoes Bauman and Vecchi (2004) in his effort to bridge the gap "between the "ought' and the "is"" as he lifts the "reality to the standards set by the idea - to remake the reality in the likeness of the idea" (Bauman and Vecchi 2004: 20).

The Tin Chaka performers also tried to capitalise on their new status as showbiz stars in order to achieve their idea of success. Omar Ali collected the music producers' phone numbers and started encouraging them to produce his music from the time he reached top 10. At that time, he used to introduce himself to others as "Taroka (star/idol) Omar Ali". Firoz demanded a business establishment loan of Taka 1,000 from Tushar in order to sell bronze chains in buses and trains, instead of pulling rickshaws. Hamidur (another top 10 contestant who was a rickshaw puller) planned to run a rickshaw garage. However, they were also confronted by the reality of their class status. Firoz was on one occasion challenged by the police and claimed he was a "staff" of ATN Bangla television. On another occasion, Omar Ali had a minor accident nearby ATN Bangla television. He immediately called Munni Saha (the television producer of Tin Chaka) on her cell phone and asked to be rescued. Munni Saha arrived and took him to a nearby clinic, but Omar Ali was more concerned about whether any cameraman would come to "cover" his accident (personal communication, 29 January 2009).

The formation of the self never stops but is revisited at every juncture. After winning the competition, Omar Ali moved to a better residence. He left his rickshaw-pulling job and sought work in stage shows and album recordings. He was invited to perform in a few stage programmes immediately after the competition, but the number of jobs decreased by the day. As promised in the grand finale, the Tin Chaka stars would get overseas performing jobs, especially in Malaysia, Singapore and Dubai but none of these materialised. Even the recording of his album as part of the event was delayed for unknown reasons. At this point in time, Omar Ali metaphorically expressed his situation as that of a person who lived on bread and leaves on one side of the river bank but was suddenly offered a journey by boat to the other side where fruits and meat awaited. Eventually he left his home and boarded the boat but it led him only to the middle of the river where 
his journey ended. He felt deserted at this point while both his home and destination were almost equal impossibilities (personal communication, 27 December 2008).

The short-listed contestants no longer seemed to be members or representatives of the community they had come from. In the audition rounds or even the first grooming sessions, they still showed communal feelings and respect to each other. During the top 10 round, they remained sympathetic to Shishir and Tushar and quite often supported them in public. But as soon as the short-listing events started, they became aware of the politics of the competition; that it was not only their music performance that would lead them to the top, but also their overall performativity. Firoz was the first to receive the producer's attention as a "potential" winner and he shared this with his fellow competitors, which was not necessarily appreciated. According to the producer, that kind of personal communication was meant only to enhance the quality of his performance, not to promise anything specific. Mukhles similarly received the same message that the judges had been "thinking" about him. These mysterious transmissions, sometimes through a production boy or a cameraman, sometimes through the smile of or a warm hug from the owner of the channel, made contestants suspicious of and competitive towards each other. They started lobbying with different people in the company. In this process, the "promiscuous" character of Firoz and the "cheating" of Mukhles and Abdur Rahman, basically anything regarding their personalities and professions, were revealed. From this experience, Omar Ali tried to learn what was expected of a Tin Chaka idol. Omar Ali neither had hopes nor did he receive any "assurance" initially. But he understood quite well that a "star" from the urban poor should be a person of character; he must be amicable and down to earth. The expulsion of "misguided" youths like Firoz opened an opportunity for him, and he played his part quite well. According to the producer, Omar Ali was very clever and there was a gulf between his earlier behaviour and the way he started behaving after being awarded. Neither Omar Ali nor any of the top 10 contestants showed politeness to each other anymore; rather they were greedy, impatient and frequently slandered each other (personal communication, 29 January 2009).

There is no doubt that winning this competition was seen by the contestants as an exit from their miseries, and a path through which they could climb in class status as well. But this kind of competitiveness does not come out from the crisis of a social identity; rather it constitutes a performative stance around the question of identity, based on a set of 
operational codes that is often not homogenous in character. At the perceptual level, Tin Chaka was not presented as a competition; rather it appeared as a "charity" event with benevolent high-status actors. The presenter of this programme, Mr. Asaduzzaman Noor, a leading theatre icon and the then member of parliament in Bangladesh, took part as a presenter for the first time in his life because of his empathetic stance towards the poor. Mamtaz, the most famous music icon of Bangladesh, volunteered as the supreme judge in the event and pledged Taka 1 lakh (USD1,500) from her personal account to the top 10 contestants. Then, another minister of the government also pledged Taka 1 lakh to the last 10 contestants who reached top 20 . At one time, such declarations from the empathetic elite of the society became common but many of the pledges were never fulfilled. As a matter of fact, the only person who did not take this programme as a "charity" was the former rickshaw puller and music personality, Akbar. When requested to perform the title song of the programme, Akbar asked for his remuneration. That surprised the event producers and was taken as a "selfish" behaviour of a former member of the urban poor toward his fellows. The presentation of the show as a charitable undertaking clearly shows how the urban poor is viewed as an ideological entity in the culture industry. Departures from this position by contestants who produce false statements, make envious remarks about each other, and whose search for an alternative professional engagement, however intended though, are basically a form of cultural resistance against these prevalent forms of ideological domination wrapped in the idea of charity. However, despite these behaviours of resistance, the Tin Chaka performers had to adopt a certain moral code that was defined by the upper and middle classes. Involved in this understanding was an explicit acknowledgement of their poverty; at the same time, they needed to perform well.

Even the audience of this programme, which comprises non-viewers of the traditional television programmes as well, was not relied on as "safe" judges in choosing the perfect music idol. Therefore, a complex procedure of judgment was adopted for Tin Chaka: a 50-50 split between judges and SMS-voters through which the intellectual and moral leadership of the educated class can be ensured in the process of the idol selection. While SMS-voters were assumed to have better appreciation of the "subaltern" performance, the panel of judges leaned towards awarding an all-rounder and well-groomed performer. The contestants, by performing identities in a two-faced way, tried to open a space in which to negotiate with the a priori understanding and ideological position taken by the culture industry. 


\section{CHARITY AND EXCLUSION}

They did not learn decency, and took charity for granted.

(The Tin Chaka Producer, personal communication, 29 January 2009)

The Tin Chaka event was completed in October 2008 and a declaration about the show's continuation was given at the grand finale. The promise was made by the owner of ATN Bangla, supported by the representative of Square Group and instantly acknowledged by the cultural elite of the city. Shishir and Tushar, the once-initiators of the programme who thought they held the moral copyright to the idea of Tin Chaka, also made separate commitments to the press in order to continue this programme with another channel. Nonetheless, Tin Chaka was not continued in the following years. The producer subtly blamed the corporate sponsor of Tin Chaka for its discontinuation (telephone follow-up, 10 September 2009). The corporate sponsor however blamed the global recession for their inability to provide support. Tushar on the other hand blamed the oligopolistic system of television media in Bangladesh, which discouraged the other channels from competing with ATN Bangla for the programme, and so on. Given the context, what exactly was the cause of the discontinuation of Tin Chaka? Was there something happening beyond the production level?

The Tin Chaka producer, Munni Saha, often claimed that the Television Rating Points (TRP) ${ }^{6}$ of Tin Chaka was "very impressive" since the beginning. However, she did not mention the exact figure. But, if the TRP response was not the cause of the discontinuation of Tin Chaka, then the only reason would be ideological, as no other popular programmes have been stopped due to the recession. In her interview, the producer talked about the "erratic" behaviour of the Tin Chaka contestants which irritated the other television and music producers. She even claimed that she did not promote any of the top three contestants to people who sought her help in contacting music performers for live events. Instead, she recommended a contestant in the top 20 round from the competition because that person had enough decency and therefore was "safe" to recommend. At this point, the discontinuation of Tin Chaka becomes more significant. As mentioned earlier, despite its professional management and corporate intentions, the performative expression of Tin Chaka could not get away from giving the impression of a charity programme (as shown in Figure 3). 


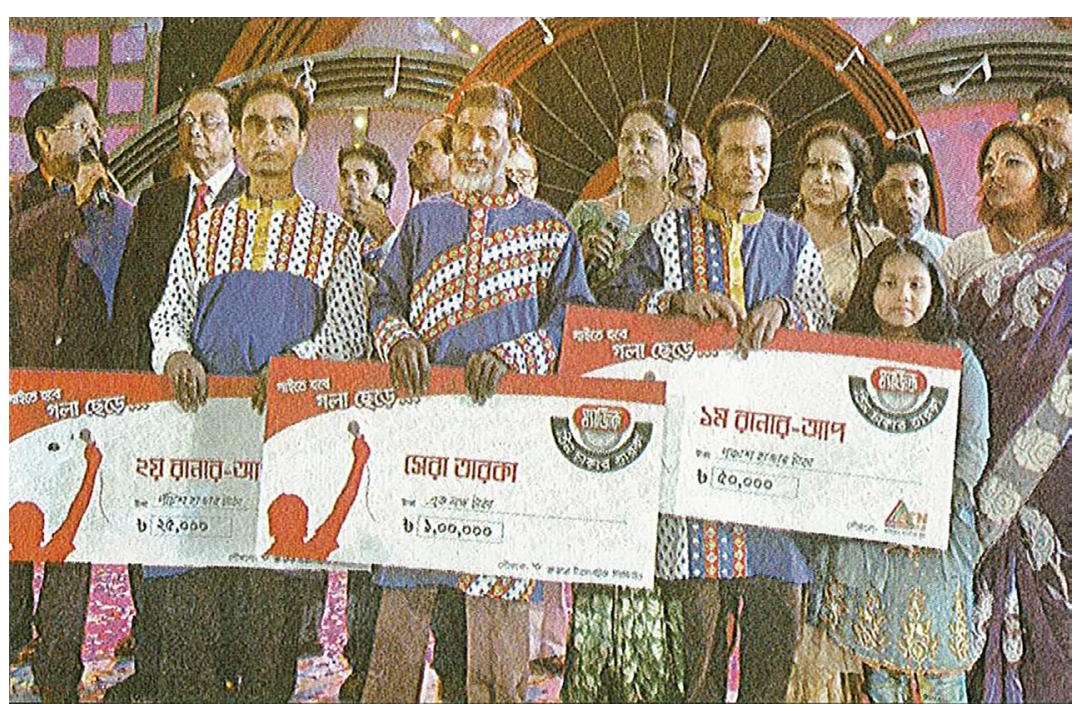

Figure 3: Tin Chaka winners and the empathetic elite join together for a photo session in the prize-giving ceremony (Prothom Alo 2008c).

Cultural commodities always serve the purpose of their creator's class and the masses only gain a bare minimum from them (de Certeau 1997: 119). As noted by the producer, a television programme in Bangladesh has always been designed for the urban educated class, which is also the default audience. Tin Chaka was no exception in this regard. For the educated audience, this charity programme worked well. The most common appreciation by this audience regarding Tin Chaka was how close or "accurate" the performance was to the "original". This is very symbolic. When a renowned pop star covers a well-known classic song, the audience is usually interested in the way the performer puts his or her own mark on that song. Contrary to expectation, the audience of Tin Chaka was concerned about the "accuracy" of the performance". This is the reason why Tin Chaka was more popular among the urban middle-class households, because this programme provided them with the moral advantage of measuring the poor according to the yardstick of the rich. Because of their moral advantage, they would even try to make excuses for the bad performance of any of the contestants. By this point, the programme had lost its competitive character and became very much a presumed moral promotion. As said earlier, the short-listed contestants also perceived the moral requirements and tried to perform according to the required norms. For the "non-viewers" among the Tin Chaka audience, this did not appear as a situation where one could be entertained. Even in terms of its reception at Korail where one of the top three contestants lived, Tin Chaka was much more popular during the audition rounds but lost attention as 
the competition went on. The "stardom" of poor contestants was heavily criticised and often savagely by those of the same social class, perhaps as a form of rejection of the charity which was evident in the programme content. Instead of coming out as music heroes, these Tin Chaka performers appeared before the urban poor audience more as "greedy" jokers.

Why have the politics of charity been rejected by the urban poor audience? In Bangladesh, the concept of charity is almost unknown to the slum dwellers. The urban poor inhabit a space that does not exist in the formal geography of the city and yet they pay as much as the rich do for their rent and amenities. Indeed, the rent charged at Korail is one of the highest in Dhaka based on a per square-foot calculation. The urban poor in fact pay the corporate rate for electricity, which is much higher than the designated residential rate paid by other city dwellers. For every service, they have to pay a much higher rate than the rich. Even street beggars must pay to beg at certain locations. This is how the urban informal economy is overexploited. On the other hand, the donor-funded NGOs are getting increasingly "entrepreneurial" instead of being charitable, in order to "sustainably" address the needs of the poor.

Moreover, the charity-based programme of Tin Chaka has another implication related to the urban poor's cultural identity. In most of the previous cases, music performers from subaltern background could not retain their "good" image in the eyes of the cultural elite. Nolok, the first music idol of Bangladesh, was "spoiled" by the stardom he achieved as a popular singer. The same happened to Akbar. Most of the complaints concerned their "moral" character. For similar reasons, Firoz was expelled from Tin Chaka. Thus Omar Ali, a man in his mid 50s, became an automatic alternative. He understood the "moral" requirements of the competition and played this card quite well. Omar Ali was awarded not only because he performed well in this competition, but also because he was able to perform the moral requirements of being an idol. According to the producer, they were looking for an idol who could survive in the music industry and not have any scandals. As Omar Ali told me, after the "expulsion" of Firoz, he was advised by the producer not to lose his head as they were thinking about him "seriously"! Therefore, Omar Ali was taken as an ambassador of the brand's values that were handed down by the ruling class and transmitted among the urban subaltern. It was in this way that Tin Chaka carried a sense of moral supremacy of the ruling elite of the city, who looked for loyalty among the "others". Therefore, the playing down of Tin Chaka by the urban poor audience is basically an indication of their unwillingness to take part in this 
loyalty game. This is another way of expressing their identity; as said by Max Frisch, identity is the rejection of what others want you to be (quoted in Bauman and Vecchi 2004: 38). The Tin Chaka music contest, despite its subaltern outlook, is basically a tricky ideology package made for the urban poor in order to "teach" them the norms of the ruling society, to provide them with a credible identity of a moral, loyal and modestly aspiring city poor.

As said before, the urban folk music was cast aside throughout the competition; contestants were offered either folk songs or pop music to perform. Therefore, apart from the charitable intentions, the visual media is also politically motivated in the event of Tin Chaka: it promotes the urban poor, but not their hybrid songs. In doing so, it becomes a wish-fulfilling project for the lost battle of the cultural elite that was fought in the music industry earlier (Mohammad 2013). By expelling urban folk music from Tin Chaka, the "taste" and "class" of popular music in the city have been reassigned; and by focusing on the urban poor, the emerging power of their music consumerism is acknowledged. On a symbolic level, the promotion of the urban poor to the level of performers from that of listeners works as compensation here for the expulsion of urban folk music. However, the discontinuation of Tin Chaka also suggests that this compensation package was not been taken up.

\section{CONCLUDING REMARKS}

The case of Tin Chaka displayed a failure in understanding the cultural formation of the city's urban poor and instead produced the elite's perception of what the urban poor should be; the exclusion of urban folk music from this competition reinstates this. Moreover, it decodes the hegemonic inscription of the cultural elite in a specific manner, and this has happened in the format of a television reality show which has often been seen as an example of the democratised media. But such a "demotic turn" of the media does not necessarily bring elements of democratisation, as has been persuasively argued by Turner (2010: 173):

[T]here is little in the shifts in the current formats, platforms or behaviour of the media to encourage a view that something fundamental has happened which comprehensively rearranges the power relations currently framing the interaction between an ordinary person and the media. 
This somewhat cynical remark on the inflated expectations regarding the connection between ordinary people and the media has appeared to be prophetic in the case of the Tin Chaka experience. At its outset, Tin Chaka can be viewed as an instance of the "democratisation" of the media at its best which has brought the urban poor to the screen. But the price of such "democratisation" is high as the short-lived stardom has also created a long-term identity crisis among its contestants. Moreover, the myth of "democratisation" in the media is highlighted especially in the context of a disadvantaged population. In this case, television regained its ideological role as a preacher and teacher of civil norms, this time neither by itself nor on behalf of the state, but on behalf of a certain class that claims to have the moral and intellectual leadership of the city. The subjects, whom we grossly termed here as the "urban poor", at first appeared docile enough not to show any hostility towards the dominant cultural norms of the educated classes and came to participate in this competition with the similar mind set. But when they turned out to be unpredictable and unruly puppets, the popular reality show could not continue with the same format. The Tin Chaka show, which carried the moral and ideological expectations of the cultural elite had to constantly negotiate with its seemingly docile but somewhat unpredictable subjects to appropriate the most from the suddenly empowered subcultural identity of the urban poor in Dhaka.

\section{ACKNOWLEDGEMENTS}

The narrative of this article has been taken mostly from one of the chapters of my $\mathrm{PhD}$ dissertation titled "Popular Music, Reality Television and the Cultural Identity of the Urban Poor in Dhaka" which was defended in 2013 under a scholarship provided by the University of Queensland, Australia. In addition, I would like to offer my sincere gratitude to the University of Queensland, Australia, for the grant and the award, my mentor Professor Emeritus Graeme Turner for his time and invaluable guidance, and the ATN Bangla Television, the organiser of Tin Chakar Taroka, for providing me with unrestricted access to their resources, meetings, rehearsals and programmes during the competition. 


\section{NOTES}

* Dr. Din M. Sumon Rahman is Professor of the Department of Media Studies and Journalism and Director of the Center for Critical and Qualitative Studies at the University of Liberal Arts Bangladesh (ULAB). He obtained his $\mathrm{PhD}$ in Cultural Studies from the School of English, Media Studies and Art History, the University of Queensland, Australia.

1 See https://www.huffingtonpost.co.uk/entry/pop-idol-where-are-they-now_uk_57f52 337e4b0052b8ffcc64d

2 Small shops from where people without cell phones can make calls in exchange of money.

3 This is seen in the removal of SB, the company's logo, from the banners and backdrops of the programme.

4 One television promotion of "Magic tooth powder" often shown during Tin Chaka was a story about an auto rickshaw driver who, when asked by his customer about the charge for a trip, was unable to spell it out distinctly enough for the customer (an urban educated middle class) to understand. The customer had a hard time understanding him and advised the driver "to speak up loudly" in future. The driver comes home only to find that the "Magic tooth powder" is a magic solution that enables him to speak up loudly. Here again, "Magic tooth powder" has been promoted as a teaching package provided by the urban educated class.

5 A weekly musical performance at Korail slum, led by a musician Jakir Sarker who ran a shop in the slum during day time. On every Thursday night, Abdur Rahman Khokon and other slum dwellers gathered at Jakir's premises and had an in-house music performance until very late in the night. Generally, Thursday nights have been observed through music by people from esoteric traditions all over Bangladesh.

6 TRP measures the popularity of a television programme in the audience that has been made for the advertisers.

\section{REFERENCES}

Abu-Lughod, L. 2005. Dramas of nationhood: The politics of television in Egypt. Chicago: University of Chicago Press. https://doi.org/10.7208/chicago/ 9780226001982.001.0001

Burgess, R. G. 1990. In the field: An introduction to field research. London: Routledge. Baudrillard, J. 2001. Selected writings, ed. Poster, M. Stanford: Stanford University Press. Baudrillard, J. and Maclean, M. 1985. The masses: The implosion of the social in the media. New Literary History 16 (3): 577-589. https://doi.org/10.2307/468841

Bauman, Z. and Vecchi, B. 2004. Identity: Conversations with Benedetto Vecchi. Cambridge: Polity.

de Certeau, M. 1997. Culture in the plural, trans. Conley, T. Minneapolis: University of Minnesota Press.

Hartley, J. 1999. Uses of television. London: Routledge. 
Jacobs, S. 2007. Big Brother, Africa is watching. Media, Culture and Society 29 (6): 851868. https://doi.org/10.1177/0163443707081691

Lockard, C. A. 1998. Dance of life: Popular music and politics in Africa. Honolulu: University of Hawai i Press. https://doi.org/10.1515/9780824862114

Mohammad, D. 2013. Producing the urban poor in Dhaka: Ideological warfare and culture-clash in music videos. Journal of Creative Communications 8 (1): 29-44. https://doi.org/10.1177/0973258613512550

. 2014. Urbanizing folklore, folkloricizing the urban: Cultural communication between the urban poor and popular music in Dhaka. Asian Journal of Communication 24 (5): 407-420. https://doi.org/10.1080/01292986.2014.903426

Moran, A. 2009. TV formats worldwide: Localizing global programs. Bristol: Intellect.

Prothom Alo. 2008a. Omar Ali idol hote chan [Omar Ali wants to be idol], 1 November, 17. 2008b. Gorib manusher golay gaan [Music in poor people's singing], 15 October, 17. .2008c. Tin Chaka winners and the empathetic elite join together for a photo session in the prize-giving ceremony, 26 October.

Rajagopal, A. 2001. Politics after television: Hindu nationalism and the reshaping of the public in India. Cambridge: Cambridge University Press.

Tay, J. 2011. The search of an Asian Idol: The performance of regional identity in reality television. International Journal of Cultural Studies 14 (3): 323-338. https://doi.org/10.1177/1367877910391870

Turner, G. 2010. Ordinary people and the media: The demotic turn. London: Sage.

Volcic, Z. and Andrejevic, M. 2009. That's me: Nationalism and identity on Balkan reality TV. Canadian Journal of Communication Corporation 34: 7-24. https://doi.org/ 10.22230/cjc.2009v34n1a2113 